\title{
Volumic activities measurements and equivalent doses calculation of indoor 222Rn in Morocco
}

\author{
Abdelmajid Choukri, Oum Keltoum Hakam \\ Department of Physics, University of Ibn Tofail, Faculty of Sciences, Kenitra, Morocco \\ [Presented at the $4^{\text {th }}$ African Regional IRPA congress (AFRIRPA04), which was held from September 13-17, 2014 in Rabat, Morocco. This paper \\ was reviewed and accepted by the scientific committee of the $4^{\text {th }}$ African Regional IRPA congress]
}

\section{Conference Proceeding}

\begin{abstract}
Purpose: As a way of prevention, we have measured the volumic activities of indoor ${ }^{222} \mathrm{Rn}$ and we have calculated the corresponding effective dose in some dwellings and enclosed areas in Morocco. Seasonal variation of Radon activities and Relationships between variation of these activities and some parameters such height, depth and type of construction were also established in this work. Methods: The passive time-integrated method of using a solid state nuclear track detector (LR-115 type II) was employed. These films, cut in pieces of $3.4 \times 2.5 \mathrm{~cm}^{2}$, were placed in detector holders and enclosed in heat-scaled polyethylene bags. Results: The measured volumic activities of radon vary in houses, between 31 and $136 \mathrm{~Bq} / \mathrm{m}^{3}(0.55$ and $2.39 \mathrm{mSv} /$ year $)$ with an average value of $80 \mathrm{~Bq} / \mathrm{m}^{3}\left(1.41 \mathrm{mSv} /\right.$ year). In enclosed work area, they vary between $60 \mathrm{~Bq} / \mathrm{m}^{3}(0.38 \mathrm{mSv} /$ year) in an ordinary area to $1884 \mathrm{~Bq} / \mathrm{m}^{3}$ (11.9 mSv/year) at not airy underground level of $12 \mathrm{~m}$. the relatively higher volumic activities of ${ }^{222} \mathrm{Rn}$ in houses were measured in Youssoufia and khouribga towns situated in regions rich in phosphate deposits. Measurements at the geophysical observatory of Berchid show that the volumic activity of radon increases with depth, this is most probably due to decreased ventilation. Conclusion: The obtained results show that the effective dose calculated for indoor dwellings are comparable to those obtained in other regions in the word. The risks related to the volumic activities of indoor radon could be avoided by simple precautions such the continuous ventilation. The reached high value of above $1884 \mathrm{~Bq} / \mathrm{m}^{3} \mathrm{don}$ 't present any risk for workers health in the geophysical observatory of Berchid because workers spend only a few minutes by day in the cellar to control and reregister data.
\end{abstract}

Keywords: Indoor Radon; Workplaces; Radioprotection; ionizing Radiations; Effective Dose; Natural Radioactivity

\section{Introduction}

Radon gas (222Rn) is commonly found in the environment and is known to be one of the principal sources of natural radiation exposure among human beings. Most of this exposure occurs inside homes, where many hours are spent each day and where the volumic activity of radon is usually higher than outdoors. It has been the subject of numerous studies and investigations in the word. ${ }^{1-6}$

The human environment is one in which ionizing radiations are present at all time and at all places on the earth from the deepest cellars to the highest mountains and on into space. Radon and its decay products are present wherever radium and thorium exist in the earth or in any planetary material. In the terrestrial environment, the inhaled radon isotopes and their daughter products make up almost two-thirds of the total dose to living tissue.

Radon is a naturally occurring radioactive gas that originates from the decay of uranium in rocks and soils. It is colorless, odorless, and tasteless and can only be measured using special equipment. It is known that radon-rich air is drawn out of underlying rock, soil, or even building materials and seeps through the floors and walls into homes. When radon surfaces in the open air, it is quickly diluted to harmless concentrations through atmospheric dilution processes. But when it enters an enclosed space, such as a house or other buildings, it can sometimes accumulate to unacceptably high concentrations due to the confinement. Indoor reduced ventilation may enable radon and its decay products to reach levels that are orders of magnitude above the outdoor levels. ${ }^{7}$ Indoor radon levels are governed by many factors, such as local geology, atmospheric conditions, air exchange rate, wind velocity, and the orientation of the house, as well as the habits of the house occupants. Generally, the radon levels are different in different rooms of the same house, the maximum concentration being in the underground cellars. ${ }^{8}$

In indoor air, radon decay products may be attached to ambient aerosols and when inhaled can be retained in the lung and deliver a dose to its walls by alpha particle emission. As a

Corresponding author: Abdelmajid Choukri; Department of Physics, University of Ibn Tofail, Faculty of Sciences, Kenitra, Morocco.

Cite this article as: Choukri A, Hakam OK. Volumic activities measurements and equivalent doses calculation of indoor 222Rn in Morocco. Int J Cancer Ther Oncol 2015; 3(3):331. DOI: 10.14319/ijcto.33.1 
consequence of the high proportion of time spent indoors and the elevation of indoor radon concentrations relative to outdoor concentrations, most exposure to radon and its decay products occurs indoors. The inhalation of radon and radon decay products in houses is the largest contributor to the natural radiation exposure of the population, and a high number of lung cancer cases are reported annually. ${ }^{9}$ The results of various international surveys have demonstrated an increase in radon concentration levels in houses and, consequently, a continuously growing concern about its health effects to the population.

In this work, we report the results of experiments conducted to calibrate the used cellulose nitrate films LR-115 type II, the volumic activities measured by means of these films in some dwellings and enclosed work areas in Morocco and we give the calculated effective doses received by population exposed to the radon effects. Seasonal variation study of radon volumic activity and relationships between variation of this activity and some parameters such height, depth and type of construction are also discussed in this work.

\section{Methods and Materials}

The passive time-integrated method of using a solid state nuclear track detector (LR-115 type II) was employed. These films, cut in pieces of $3.4 \times 2.5 \mathrm{~cm}^{2}$, were placed in detector holders and enclosed in heat-scaled polyethylene bags. Calibration measurements were made giving a calibration factor of 0.58 tracks.cm ${ }^{-2} / \mathrm{kBq} . \mathrm{h} . \mathrm{m}^{-3}$ at the reference "removed thickness" of $6 \mu \mathrm{m} .{ }^{10-11}$ After exposure, the films were chemically etched in sodium hydroxide $(2.5 \mathrm{~N})$ at $60^{\circ} \mathrm{C}$ for 120 minutes. The tracks produced were counted with an optical microscope and the background was then subtracted. After normalizing the track density to a removed thickness of $6 \mu \mathrm{m}$, the number of tracks per $\mathrm{cm}^{2}$ was correlated to the volumic activity of radon. Figure 1 show the relationships established between the volumic activity of ${ }^{222} \mathrm{Rn}$ and the density of counted tracks.

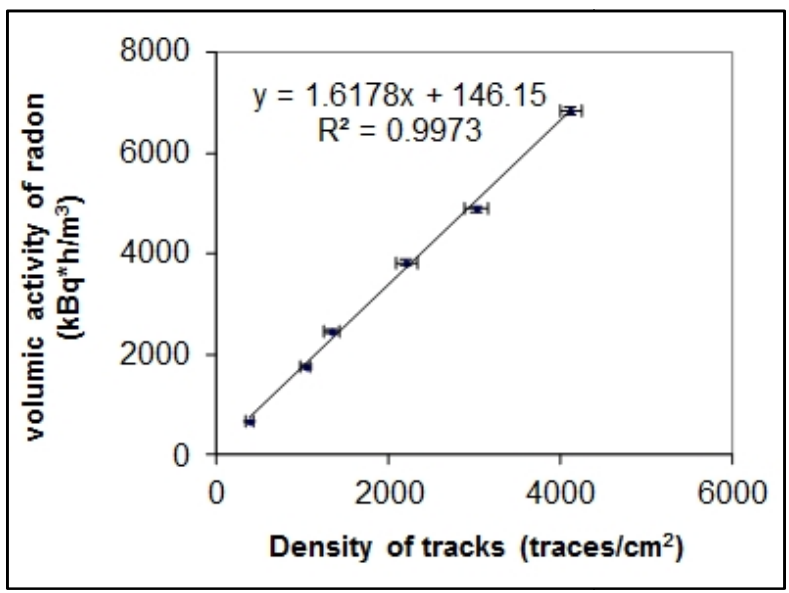

FIG. 1: Calibration curve of cellulose nitrate films LR-115 type II.

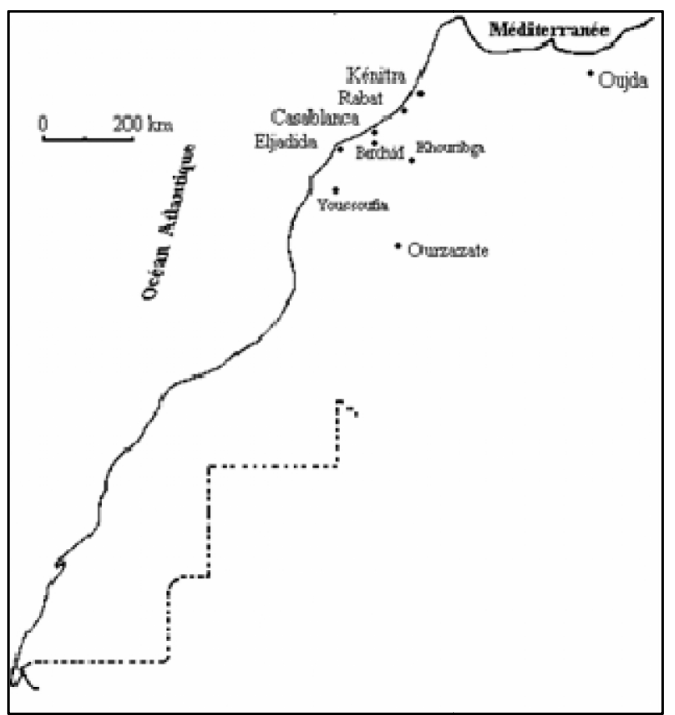

FIG. 2: Map showing the stations of radon measurements.

In houses, detectors are exposed in the most frequented room. They are generally hung on the ceiling by a support. Detectors are got back after an exposure time of about 3 months. If the result of the first measure is below $5 \mathrm{~Bq} / \mathrm{m}^{3}$, a priori abnormal situation, or exceeds $400 \mathrm{~Bq} / \mathrm{m}^{3}$, a second measure is realized to confirm the result. Detectors are then developed and counted following the procedure described by Hakam. ${ }^{10-11}$

\section{Stations of radon measurements}

We implanted our stations of measure in some regions of Morocco. However we were able to make measures only in the places where we found voluntary correspondents having agreed to install LR-115 detectors and to return back them to us after exposure. So, we made measures in houses in the following cities: Rabat, Casablanca, Kenitra, El Jadida, Berchid, Khouribga, Youssoufia, Ouarzazate and Oujda. These Cities were chosen in the following way:

- Rabat, Casablanca, Kenitra, El Jadida are cities where there is a big population.

- Khouribga and Youssoufia are cities situated in rich regions in deposits of phosphates.

- Ouarzazate is in the South of Morocco (dry climate).

- $\quad$ Oujda is in the northwest of Morocco.

The workspaces, in which we were interested, are:

- The laboratory of Nuclear physics in the Faculty of Science of Rabat.

- A room in underground.

- A room in the first floor.

- Two processing plants of Morrocan ores.

- The geophysical observatory of Berchid.

- A room at the ground floor.

- A closed underground cellar characterized by three levels. 


\section{Results and Discussion}

The measurements were performed in 9 dwellings and 7 enclosed work areas in some regions of Morocco. Results for dwellings are given in Table 1 and these for enclosed work areas are given in Table 2 . The exposure period of films in dwellings and in enclosed work areas varied between 2 and 4 months. The given results are an average of at least 2 measures by locality and at least in two houses.

The effective dose per unit exposure to radon and radon progeny was obtained using the so-called dose conversion convention as defined by ICRP. ${ }^{12-13}$ This approach compared the detriment per unit exposure to radon and its progeny with the total detriment associated with unit effective dose. The values given were $5 \mathrm{mSv}$ per WLM (Working level month) for workers and $4 \mathrm{mSv}$ per WLM for members of the public. $1 \mathrm{~Bq} / \mathrm{m}^{3}$ of radon during 1 year $=4.410^{-3} \mathrm{WLM}$ at home and $1 \mathrm{~Bq} / \mathrm{m}^{3}$ of radon during 1 year $=1.2610^{-3} \mathrm{WLM}$ at work assuming $7000 \mathrm{~h}$ per year indoors or 2000 hours per year at work and an equilibrium factor of 0.4 .

TABLE 1: Volumic activities of ${ }^{222} \mathrm{Rn}$ and effective doses in indoor dwellings

\begin{tabular}{ccc}
\hline \hline Town & $\begin{array}{c}\text { Volumic activity } \\
\text { of }{ }^{222} \mathrm{Rn}\left(\mathrm{Bq} / \mathrm{m}^{3}\right)\end{array}$ & $\begin{array}{c}\text { Effective dose } \\
(\mathrm{mSv} / \text { year })\end{array}$ \\
\hline Berchid & $76 \pm 8$ & $1.34 \pm 0.14$ \\
Casablanca & $31 \pm 3$ & $0.55 \pm 0.05$ \\
El Jadida & $47 \pm 4$ & $0.83 \pm 0.07$ \\
Ouarzazate & $99 \pm 5$ & $1.74 \pm 0.09$ \\
Oujda & $83 \pm 7$ & $1.46 \pm 0.12$ \\
Rabat & $64 \pm 5$ & $1.13 \pm 0.09$ \\
Kénitra & $59 \pm 6$ & $1.04 \pm 0.11$ \\
Youssoufia & $124 \pm 8$ & $2.18 \pm 0.14$ \\
Khouribga & $136 \pm 9$ & $2.39 \pm 0.16$ \\
\hline \hline
\end{tabular}

TABLE 2: Volumic activities of ${ }^{222} \mathrm{Rn}$ and effective doses in enclosed work areas.

\begin{tabular}{ccc}
\hline \hline Enclosed work area & $\begin{array}{c}\text { Volumic activity } \\
\left(\mathrm{Bq} / \mathrm{m}^{3}\right)\end{array}$ & $\begin{array}{c}\text { Effective dose } \\
(\mathrm{mSv} / \text { year })\end{array}$ \\
\hline $\begin{array}{c}\text { Laboratory of nuclear physics (Rabat) } \\
\text { Local for practical nuclear studies } \\
\text { (Faculty of Sciences, Rabat) }\end{array}$ & $60 \pm 4$ & $0.38 \pm 0.03$ \\
Factory 1 & $68 \pm 6$ & $0.43 \pm 0.04$ \\
Factory 2 & $435 \pm 4$ & $2.74 \pm 0.03$ \\
Geophysical Observatory of Berchid \\
(Ground level) & $142 \pm 15$ & $0.90 \pm 0.09$ \\
$\begin{array}{c}\text { Geophysical Observatory of Berchid } \\
\text { (Cave at -12 meters) }\end{array}$ & $63 \pm 5$ & $0.40 \pm 0.03$ \\
\hline \hline
\end{tabular}

Table 1 show the relatively higher indoor volumic activities of ${ }^{222} \mathrm{Rn}$ in Youssoufia and khouribga towns situated in regions rich in phosphate deposits. Measurements at the geophysical observatory of Berchid show that the volumic activity of radon increases with depth, this is most probably due to decreased ventilation.
The radon would be the second cause of death by lung cancer (after the tobacco). In 1990, the European Commission fixed two limits, the one for the existing houses $\left(400 \mathrm{~Bq} / \mathrm{m}^{3}\right)$, the other one for the future constructions $\left(200 \mathrm{~Bq} / \mathrm{m}^{3}\right)$. In 1993 , the CIPR proposes a range between a low value $200 \mathrm{~Bq} / \mathrm{m}^{3}$ corresponding to an effective dose value of $3 \mathrm{mSv} /$ year) and a high value $600 \mathrm{~Bq} / \mathrm{m}^{3}$ corresponding to an effective dose value of $10 \mathrm{mSv} /$ year) beyond which it considers that it is justified almost always to act. The effective dose was different between homes and workplaces largely because of the different number of hours spent at each. For workplaces the corresponding range of permit concentrations of radon was 500-1500 Bq/m³ . In 1996, the European directive N 96/29, imposes the inventory of all the workplaces susceptible to provoke an increased exposure to radon. The first occupations concerned by the exposure in the radon were the miners. ${ }^{14}$

Our measurements showed volumic activities of radon vary in Houses, between 31 and $136 \mathrm{~Bq} / \mathrm{m}^{3}$ with an average value of $80 \mathrm{~Bq} / \mathrm{m}^{3}$. This value is comparable to those found in the other regions of the word. In Enclosed work area, they vary between $60 \mathrm{~Bq} / \mathrm{m}^{3}$ in an ordinary area to $1884 \mathrm{~Bq} / \mathrm{m}^{3}$ at not airy underground level of $12 \mathrm{~m}$. For example, values of 4150 and 5122 have also been found in two deep cellars in Orléans in France. ${ }^{15}$

The calculated effective dose in houses varies between 0.55 and $2.39 \mathrm{mSv} /$ year with an average value of about 1.41 $\mathrm{mSv} /$ year. In enclosed areas it varies between 0.38 and 11.9 $\mathrm{mSv} /$ year with an average value of about $2.8 \mathrm{mSv} /$ year. Thus the radon concentration levels found in this study are below the action level recommended by the ICRP. The relationships between volumic activities of indoor radon and seasonal variations have already confirmed by Hakam. ${ }^{11}$

The data of this table show a maximal value of $95 \mathrm{~Bq} / \mathrm{m}^{3}$ in winter and a minimal value of $37 \mathrm{~Bq} / \mathrm{m}^{3}$ in summer, that is a report of 2.5. This difference results especially from an important aeration in summer. Both seasons Spring and Autumn are respectively characterized by average concentrations of radon of $66 \mathrm{~Bq} / \mathrm{m}^{3}$ and $60 \mathrm{~Bq} / \mathrm{m}^{3}$. These seasonal characters are marked themselves by variations during the day, maximal during the night and minimal during the day. This is explained by the closure of doors and windows during night, preventing the renewal of air in the house. Houses can be classified in two categories following the nature of building materials, stones on one hand and other materials on the other hand (bricks, perpend, concrete).

TABLE 3: Seasonal variation study of Radon volumic activity.

\begin{tabular}{cc}
\hline \hline Exposition season & $\begin{array}{c}\text { Volumic acti- } \\
\text { vity }\left(\mathrm{Bq} / \mathrm{m}^{3}\right)\end{array}$ \\
\hline Summer & $37 \pm 2$ \\
Autumn & $60 \pm 4$ \\
Winter & $95 \pm 7$ \\
Spring & $66 \pm 4$ \\
\hline \hline
\end{tabular}


We observed a difference between houses in stones and the other constructions. The volumic activity of the radon is 47 $\mathrm{Bq} / \mathrm{m}^{3}$ in a house in stones and $31 \mathrm{~Bq} / \mathrm{m}^{3}$ in the other construction not in stones. These values are obtained during the same period of exposure in two nearly houses in El Jadida region.

TABLE 4: Radon volumic activities according to the height.

\begin{tabular}{cc}
\hline \hline Floor & Volumic activity $\left(\mathrm{Bq} / \mathrm{m}^{3}\right)$ \\
\hline $1^{\text {st }}$ & 67 \\
$2^{\text {nd }}$ & 54 \\
$3^{\text {th }}$ & 47 \\
$4^{\text {th }}$ & 32 \\
\hline \hline
\end{tabular}

As the main source of radon in houses is the basement, we can expect to observe differences between dwellings results in the various floors of a building. This aspect is shown by the data collected in the various floors of a building situated in the Kénitra city. We so measured radon volumic activities varying from $67 \mathrm{~Bq} / \mathrm{m}^{3}$ in the first floor to $32 \mathrm{~Bq} / \mathrm{m}^{3}$ in the fourth floor (Table 4). Thus the activity of the radon decreases with the height.

TABLE 5: Radon volumic activities According to the depth

\begin{tabular}{llc}
\hline \hline & Depth & Volumic activity $\left(\mathrm{Bq} / \mathrm{m}^{3}\right)$ \\
\hline Ground Level & Office & $58 \pm 6$ \\
& Room & $68 \pm 8$ \\
\hline \multirow{4}{*}{ The cellar } & $1^{\text {st }}$ level & $1208 \pm 184$ \\
& $(-4 \mathrm{~m})$ & \\
& $2^{\text {nd }}$ level & $1499 \pm 100$ \\
& $(-8 \mathrm{~m})$ & \\
& $3^{\text {th }}$ level & $1884 \pm 119$ \\
& $(-12 \mathrm{~m})$ & \\
\hline \hline
\end{tabular}

In order to check the effect of the depth on the variation of the Radon volumic activity, we took advantage of our access to the geophysical observatory of Berchid to make our measures at three underground levels. The obtained results are given in the Table 5 .

We notice a big difference between the activities of the radon of the ground floor and those in the different levels of the cell -ar. This explains by the fact that the cellar is closed in a conti -nuous way and is not equipped with a system of aeration.

\section{Conclusion}

The measurements performed in 9 dwellings and 7 enclosed work areas in different regions of Morocco show that:

- The obtained values of volumic activities of radon in dwellings and in enclosed work areas and the calculated effective dose are comparable to those obtained in the other regions in the word and they are below the action level recommended by the ICRP (3 to $10 \mathrm{mSv} /$ year corresponding to volumic activities from 200 to $600 \mathrm{~Bq} / \mathrm{m}^{3}$ for houses and from 500 to $1500 \mathrm{~Bq} / \mathrm{m}^{3}$ for workplaces)

- The relatively higher volumic activities of ${ }^{222} \mathrm{Rn}$ in Youssoufia and khouribga towns are obtained because Youssoufia and khouribga are situated in regions rich in phosphate deposits.

- The volumic activity of radon increases with depth, this is most probably due to decreased ventilation. This is the case of the geophysical observatory of Berchid where the reached high value of above $1884 \mathrm{~Bq} / \mathrm{m}^{3}$ don't present any risk for workers health in the geophysical observatory of Berchid because workers spend only a few minutes by day in cave to control and reregister data.

- A maximal value of radon volumic activity was measured in winter and a minimal value of this activity was measured in summer. This difference results especially from an important aeration in summer. The use of air conditioners in summer and the possible natural ventilation in winter help to keep concentration levels of indoor radon low.

- $\quad$ The measured volumic activities of radon depend on some parameters such type of construction, the height of building and the depth of the underground.

- $\quad$ The radon concentration levels found in this study are below the action level recommended by the ICRP.

To protect human health, efforts are always necessary to reach the effective dose of $1 \mathrm{mSv} /$ year recommended by ICRP for the public in his publication 60 and confirmed in the later publications. At present, we are working to make measures covering all the Moroccan regions with the aim of establishing a distribution map of the radon in houses, schools and workplaces in Morocco. Our purpose would also be to establish eventual relationships between radon activities and mortality because of the cancer of lungs in Morocco.

\section{Conflict of interest}

The authors declare that they have no conflicts of interest. The authors alone are responsible for the content and writing of the paper.

\section{References}

1. Ahmed N, Matiullah, Khatibeh AJAH. Indoor radon levels and natural radioactivity in Jordanian soil. Radiat Prot Dosim 1997; 71: 231-3.

2. Matiullah, Bashir A, Kudo, K, Yang X. Radon measurements in some houses of Tsukuba science city, Japan. Nucl Tracks Radiat Meas 1993; 22: 395-8. 
3. Miles JCH, Green BMR, Lomas PR, et al. Radon in UK homes: Defining the areas. Radiat Prot Dosimetry 1991; 36: 117-20.

4. Darby S, Hill D, Auvinen A, et al. Radon in homes and risk of lung cancer: collaborative analysis of individual data from 13 European case-control studies. BMJ2005; 330:223.

5. Rahmana SU, Anwara J, Matiullah B. Measurement of indoor radon concentration levels in Islamabad, Pakistan. Radiat Meas 2008; 43: 401-4.

6. Al-Azmi D, Abu-Shady AI, Sayed AM, Al-Zayed Y. Indoor radon in Kuwait. Health Phys 2008; 94:49-56.

7. Khan AJ. A study of indoor radon levels in Indian dwellings, influencing factors and lung cancer risks. Radiat Meas 2000; 32:87-92.

8. Virk HS. Indoor radon levels near the radioactive sites of Himachal Pradesh, India. Environ Internat 1999; 25: 47-51.

9. United Nations Scientific Committee on the Effects of Atomic Radiation. Report to the General Assembly New York: United Nations 2000: 1.

10. Hakam O, Lferde M, Berrada M. Calibration of a solid state nuclear track detector for the measurements of radon concentration in air. Appl Radiat Isot 1995; 46: 483-4.
11. Hakam O. Etude de la répartition des activités des radio-isotopes de l'uranium et du radium dans les eaux naturelles et du radon dans l'air des habitations au Maroc. Thèse d'état, Univ. Med V, Morocco, 2000:212.

12. 1990 Recommendations of the International Commission on Radiological Protection. Ann ICRP 1991; 21:1-201.

13. Protection against radon-222 at home and at work. A report of a task group of the International Commission on Radiological Protection. Ann ICRP 1993; 23:1-45.

14. EC, European Commission. On the protection of the public against indoor exposure to radon. Recommendation 90/143/Euratom, EC, Brussels, 1990.

15. Anne-Marie P. Gare au radon en toutes régions. Revue Sortir du nucléaire2003; 22: 34. 